\title{
Igbo Cultural Values and the European Influence: A Way to Redirect the Present Igbo Youths
}

\author{
Gladys Ifeoma Udechukwu \\ http://dx.doi./org/10.4314/ujah.v18i2.22
}

\section{Abstract}

The world is a mystery and very complex to finish its interpretation. As it continues to exist, numerous things and mysterious things manifest day by day. Human beings are made to live and control other things in the world. In different parts of the world, many cultures and belief systems exist. Because of the natural endowment of different regions of the world, there is bound that differences must exist in the way the people think and live their lives. It is therefore not surprise that what one part of the world practices or holds firm may not be the same with other parts of the world. Europeans have their way of life based on their environment and culture and Igbo people also have their own way of life. In living out the life, there are values and norms which help to control peoples' lives and to check the excesses. There are some negative behaviours that are not acceptable in the society. These unacceptable behaviours are called "Taboos". What is seen as taboo in Igbo land may not be seen as taboo in the European countries. It has been observed that some of the Igbo people that have come into contact with Europeans have been seriously influenced and affected by the culture of the white men in such a way that their own culture has been delegated to the background and this has affected the way they live which in most cases are contrary to the good values and norms Igbo people are known for. It is on this note that the researcher seeks to look into some of the Igbo cultural values that have been influenced by the Europeans 
and their effects on human development. With this, the Igbo people will be able to understand their cultural heritage and will go a long way to preserve and protect them. Descriptive and survey methods of research will be adopted in the course of the research.

\section{Introduction}

Values and norms, have been the collective name applied to traditional verbal materials and social ritual that have been handed down solely, or at least primarily, by word of mouths and technically by example rather than in written form. They include among others legend, fables, proverbs, riddles, myths, traditional dances and forms of drama, which are perform at holidays at community gatherings (Abrams, 1971:63).

All over the world, people in every society take pains, devote time and attention to educate the young ones to be functional adults. In most cases, these pains, devotion of time and attention to the training of young ones are geared towards impacting and transmitting culture and social knowledge that will enable them fit well in the society, and physical environment of the society in which they live. In the process of impacting the social and cultural knowledge to the young ones, different socio-cultural values and norms are used (Anagbogu, 2001:70).

These forms of values are used for social regulation and conduct. A look at the Igbo oral literature such as proverbs, songs, riddles and so on reveals the fact that these forms aim at articulating the people's world-view, explaining and demystifying certain existences in nature, emphasizing the fact that wisdom and honesty are indispensable for survival and honoring achievers. They also act as an instrument of satire not against the masses, but also 
against the rulers when they go contrary to established norms. Parents, guardians, relatives and a wider circle of kinsmen in Igbo land consider it a sacred trust of discharging their obligations as it concerned the socialization of the Igbo child (Ukeje, 1976: 54). As a matter of fact, the entire village takes part in this socialization process.

On the other hand, the Igbo youths of the current age could be seen as people who had through their interaction with the white man's formal educational and cultural practices, adroitly or partially abandoned the cultural heritage of the Igbo people formerly and at present have their way of living which is common among them, but the cultural pattern had been gradually relegated to the extent that one can hardly identify an Igbo man with his living pattern. The truth is that the pervasive drive in our present day youths seems to make them naturally open to all kinds of pervasions which are provoked by western traditions where legalization of all kinds of abominable practices and all these are sold to our young ones just in a push of button through all the available mass media.

Unfortunately and most regrettably today, immoralities and their practices are now the sailing- point or the incentive that foster a high patronage of the products from the present day entertainment industries. The $21^{\text {st }}$ century uncensored display of immoralities are now on majority of the entertainment TV cable channels, most of the lucrative musical videos today are the sexually provocative ones, our home movies today are alarmingly characterized with nudity advertisement of all kinds of sexual misconducts like, lesbianism or gay sexual relationship, sexual promiscuity among others. All these have been on the negative effects on human and economic development. Ukeje in Aguba (2005: 10) says, "African 
man, especially, the Igbo man, would like to eat like the white, drink like him, dress like him speak like the white, laugh like him"

\section{Some Igbo Cultural Values}

Values are important things in the daily life of society. That is anything getting importance in our daily life becomes our values. The origin of values is not biological but it is social production. While living in society, the values develop. Values depend upon the culture; culture varies from society to society and thus values are different in every social situation. The culture is full of values and can transmit from one generation to another. It is the cultural value of people that make them have "Norms" Norms are the rules and the guidelines which specify the behavior of an individual in a society. Norms keep a person within the boundary of society and its culture. It gives restriction about something which to do and which not to do. It moulds our behavior and gives us knowledge about wrong and right. The action or conduct of one man within the community can affect the other members for good or for evil. In other to prevent man from becoming rebellious and thus endangering the welfare of the society, there set patterns or code of behavior for the individual and community as a whole. There are certain standards or norms to be observed. These norms can be seen as moral values.

Some of the Igbo cultural values are- reverence for the Supreme God and other divinities, respect for elders, modest dressing, good character and behavior, arts and crafts characterized by hard work, type of food we eat, among others. These good values are inculcated in every Igbo child at tender age that is why there is a very good human development in the three 
domains of human development then. . These three domains may figuratively be described as belonging to the head (cognitive), the heart (affective) and the body (psychomotor). On the other hand, there are behaviours which are forbidden and must not be done. They are called "Taboo"

\section{Some Areas of European Influences on Igbo Culture}

Religious Worship: Worship is an expression of reverence and adoration to God, and by extension it also means the act of taking part in a religious service. It should be taken as human response to the perceived presence of the divine that brings man into an intimate relationship with God. The definition of worship establishes worship as a universal priority and number one responsibility of every man. An important aspect of worship is liturgy. Liturgy is the prescribe forms of ritual for public worship. It is a vehicle of communication between man and Divine Being (God). It includes prayer, singing, confession of sin, giving sacrifice or offering etc.

It has been observed by many scholars that human beings have always worship God in their cultural environment, and that God also has incarnated Himself and revealed Himself to worshippers in settings that are culturally familiar. Culture being dynamic and constantly changing, sometimes slowly and gradually at other times rapidly and dramatically, has always stood the tension with prevailing trend of western worship. As it is now, the shift in the contemporary times is more pronounced as the western worshippers borrow secularized liturgical forms from the growing entertainment industry. The trend now culturally is not even incursion of traditional values on Igbo worship (Ojofeitimi, 2016). 
Marriage: In Igbo people context, marriage is a union between a man and one or more women. It involves a process whereby the people concerned make their relationship official and permanent. In essence, marriage is a socially recognized union between spouses that establish rights and obligations between the spouses and their children, and between the spouses and their in-laws. It is practically an institution in which inter personal relationships are acknowledged. In Igbo traditional marriage before the advent of Christianity, the marriage involves the payment of bride price and wine carrying by the husband which are done in low tone without much stress and difficulty, because Igbo people believe that their daughters are not sold like material things.

But these days, in almost all the Igbo land, the bribe issue has become a burdensome task. The young groom sometimes has to go through many stages of payment of bride price involving a lot of expenditure on entertainments before the actual traditional wine carrying takes place. This has made it difficult for the young men to marry and at the same time cause the overstay of many young ladies before getting married, which later may cause the couples not being able to bear children because the wife has passed the stage of child bearing. Again there is high rate of divorce in Igbo land unlike in the olden days. This because the civilized society we live in has become more accepting of divorce and remarriage even single parenting and thus has made it easier for couples to abandon their marriages and go their separate ways. This in turn affects human development mentally and physically.

Child Upbringing: Child upbringing is the major responsibility in Igbo land. It is the sole responsibility of the parents especially mothers to bring up their children in the customs and traditions of 
the Igbo people. From the stories children heard from parents, they learn the cultures and traditions of the society. In Igbo traditional education, the cultural norms, values and customs of the society were inculcated in the mind and habits of the Igbo child through these means. After the day's work, parents and other elderly persons in the families of the children gathered them and began to teach them Igbo folktales and stories. The children were told the stories of good and bad deeds and behaviours and the rewards for such behaviours. Through this they were encouraged to do good always. These tales and stories helped to expose the children to the effects of different behavioural patterns and their likely rewards. In most of these tales and stories, tortoise is used to replace man, but at the end, the aim is usually achieved, as such stories usually end with, "This is why it is goodlbad for a person to behave like the tortoise"

In the present era, children are no longer given the good upbringing through those stories, customs and traditions; rather they are left to the mercy of different kinds of movies and horror films where they learn bad behaviours that are in opposition to their good values which in the later time affect their development as human beings. Again, at the period between adolescence and adulthood then, the child was educated in those areas of knowledge and skills that are innate in him so that he may be able to explore his talents and take up more and more of the life challenges that are inevitable for him to live a fulfilled life. Sometimes, for these youths to have an in-depth knowledge of this career undertaking, they go into apprenticeship with an employer whom they serve for a defined period. During apprenticeship, the child practices on the career of his choice and he is guided by the employer who watches and directs him where necessary. At this 
stage, the child is prepared to take the life challenges of adulthood. On the contrary, the present youths no longer want to take up life's challenges, they do not want to learn a trade or work neither do they want to go to school, but they will like to make money, ride an expensive car, live in a gorgeous house. This is why many of our youths are involve in armed robbery, cheating, kidnapping, cultism, killing and many more. All these affect human development negatively.

Furthermore, Igbo traditional education also produced children whose characters and behavioural patterns were excellent. In those days, young girls were thought to behave themselves at all time for them to get married. Okonkwo in Things Fall Apart portrayed this well, when he commanded Ezimma to sit like a woman (Achebe, 1958:40-41). This was said when Ezimma was not sitting properly before his father Okonkwo and when she was asking her father question while he was eating, forgetting that Igbo child is taught about table manner i.e. people should not talk when they are eating because pepper may go down the wrong way.

It was also found out that before the advent of western civilization; every Igbo parent trained the child to be self employed. Men taught their sons to work with their hands and to provide support for themselves than roaming about the villages. This training which they got between childhood and early adulthood was enough to help them start their own lives and not to wait for white collar jobs which are not forth coming. Thus a child grapples the activity which the family is known for and makes a good living from such.

It was also discovered that traditional practices and curriculum 
imparted in the children the traditional beliefs, customs, norms and cultural values of Igbo people and thereby helped in widening the children's knowledge and appreciation of Igbo cultural traits. This is achieved through the parents- children relationship, where the parents exposed the children to the traditional beliefs, customs and norms of the people. A child that is brought up in their own culture will never depart from it when he grows up. This was in accordance with what was written in the Holy Bible (Proverbs, 22: 6) which says, "Train up a child in the way he should go: and when he is old, he will not depart from it"

\section{Food}

Igbo people were known for local and natural foods before the coming of Europeans. They plant and eat different types of foods and vegetable naturally. The local foods are full of flavor and taste better and they have more nutrients because they have more beneficial nutrients such as antioxidants which altogether help in the good development of human beings. But with the high rate of civilization in Igbo land, Igbo people have forgotten the natural food they were endowed with and embrace modern ones. Modern foods are grown with chemical fertilizers. During the planting, the weeds are controlled with chemical herbicides. Insecticides are also used to manage pests and diseases. All these affect the produced foods which when consumed affect human development health wise.

\section{Mode of Dressing}

It is important to state that people have their traditional way of dressing and in Igbo land; our dressing is usually beautiful and modest. In the past before the coming of the white men, Igbo people do not know anything about wearing clothe. Men go by 
tying a piece of clothe around their waist just to cover their manhood, women on their own wear "Jigida" while the youths and children go stake naked. But with the coming of the white men who brought to Igbo land different clothes, Igbo people started wearing full clothe to cover their nakedness. Men and young boys wear shorts and trousers with shirts while women and young girls go by wrapper and blouse or skirt and blouse or gown. Cultural, this is how it was and how it should be. But because of the new trend in fashion and designing of the white people brought again by them, Igbo people both men, women and young ones have shifted from the good and modest dressing we were known for to the modern fashion where men perforate their ears and burn their hairs while women and young girls put on trousers and miniskirts and gowns exposing their nakedness. This type of behavior is contrary to the good cultural values Igbo people were known for and this directly and indirectly affects human development.

\section{Effects of the European Influence}

The influence of the western civilization has some negative effects on Igbo culture and tradition. These are some of the areas that are affected.

i. The Society: Misbehaviours obtainable in the present day Igbo society in general and Igbo youths in particular had to a great extent, hampered the proper growth and development of the Igbo land in general in relation to social, economical, educational and political aspects. The relative total abandonment of hard work for the acquisition of human needs and the apparent great importance attached to the short-cuts towards making ends meet had drastically affected the society in issues like leadership positions, award and parading of certificate, housing, employment, admissions into institution of 
higher learning, acquisition of wealth, social amenities and many others have been proved to be most suitably gotten through fraudulent means. No one thinks in the right direction and the few who dare to think and act morally, are considered as "morons".

What an astute society where virtually all the inhabitants desire to make wealth and other acts of achieving fame at the instance of "robbing" people around them of their rights. Obviously, nothing good but catastrophe comes out of evil-deeds. The scramble for the attainment of certain positions economically, politically, socially, academically and otherwise, had led the Igbo people to a seemingly unending decay in all facets of their lives.

ii. The Education Sector: Some young students have exchanged their study times in the schools for their engagement in immoral acts thus exchanging their times for sexual, business, domestic work etc. with some school staff and prefects. Those mostly found in this act are female students who engage in the above acts so as to be offered some money for such services, hence using same to pay for the up-grading of their marks or allow such person(s) cheat in examinations. One wonders at this juncture what becomes of the educational products of the contemporary times. It should not be a surprise when a student who has seen the nudity of the teacher or school head disrespects the said staff that collects bribe to assist or pass him or her in an examination and finally, turn down the hopes of the student. It is a known fact that bribe corrupts the mind. Many students have abandoned serious studies as the only means of passing examinations and gone into harder struggles for making money and other such demanded materials and 
activities for academic excellence as considered most appropriate.

On the students' part, an hour watch into the society would reveal that in every forty five minutes, certain mischief in the forms of fraud, cultism, robbery, bribery, truancy etc are secretly or openly unfolding in the society. Children who watch these things take place and who easily learn through imitations, grab the unfolding events and later try to practice or perform the activities they saw taking place around them as exposed by either their parents, guardians or the adult members without much thoughts on the effects thereafter. Through this, a very intelligent student who is surrounded by these gradually begins to experience some academic backwardness so soon as his thoughts start to rig morale hence resorting to engagement in fraudulent activities to make ends meet in his academics.

In trying to do this, the students may turn to become cultists, robbers, fraudsters, thugs, rapists and sex workers which all the way lead to frustration in life - the end of which is uselessness or death of the student. No wonder our youths are dying younger as a result of greed and jealousy.

iii. The Youths: Anagbogu (2005) affirms that the major effect of immorality on the youths is that the youths for one reason or another drop out of schools which end them up in abject frustrations in life. On the other hand, those who grudgingly complete their stay in schools without hard works, come out of the schools with very poor results or where they make good results, do so through crooked means - hence not being able to defend the certificates they parade. 
- The Economy: Economically, the decay had done much harm than good in that money and other valuables that could better be used to better the lots of our people, has been wrongly channeled to what does not profit to the end. Parents who aid and abet their children and wards' involvement in examination malpractices for instance or their involvement in any form of anti-social activities such like rape, tugging, robbery, cultism, alcoholism et cetera, once their children or wards are caught, they invariably spend almost all they could to ensure that these youths are saved, hence investing in worthless things.

\section{Conclusion}

Igbo people are blessed with good cultural values. It is these values that our forebears used to live their lives and were able to achieve good human development. These values are still where we left them for modern values. Therefore, if Igbo people will achieve concrete human development in our contemporary society, they should go back to the drawing board, that is, the former good cultural values they have and bring them back into their present way of life; that is, in the way they think, eat, dress, train their children, worship, work etc. It is only then that is done that they will have good human development all round.

\section{Gladys Ifeoma Udechukwu}

Nnamdi Azikiwe University, Awka

gladudechukwu@gmail.com 


\section{References}

Abrams, M.H. (1971). A Glossary of Literary Terms. $3^{\text {rd }}$ Edition.

New York: Holt Rinehart and Winston. Inc.

Achebe, C. (1958). Things Fall Apart. Great Britain: Morrison \& Gibb.

Aguba, R.C. (2005). Historical Development of Education Administration. An Unpublished Monograph.

Akogu, P.O. (199). Why Anthropology? Enugu: Future Tech

Anagbogu, M.A. (2001). "Cultural Sanctions: Implications for

Child Training Education and Counseling" in the International Journal of Social Inquiry. Vol. 1, No. 1, Awolalu, J.O.\& Dopamu, P.A. (1979). West African Traditional Religion. Ibadan: Onobonoje Press and Book Industries.

Ezenweke, E.O. \& Kanu, I.A. (Eds.), (2012). Issues in African Traditional Religion and Philosophy. Jos: Augustinian Publications

Graham, C.K. (1971). The History of Education in Ghana. London: Frank Cass and Company.

Ogbalu, F.C. \& Emenanjo, E.N. (Eds.), (1982). Igbo Language and Culture. Ibadan: University Press.

Ojofeitimi, A. (2015). "Culture and Mode of Worship" in T. Olumakaiye (Ed.). Woman of Value. Pg.6 Vol.5. Lagos: Action and Outreach Unit.

Ukeje, B.O. (1976). Education for Social Reconstruction. London and Basingstoke: Macmillan Education. 